\title{
Pergulatan Sains dan Agama
}

\section{Edwin Syarif}

Fakultas Ushuluddin UIN Syarif Hidayatullah Jakarta

edwin_syarifyahoo.com

Abstract: This paper describes the struggle of science and religion with a historical approach. The relation of both subjects has occurred in four periods: Greek, Islamic, Renaissance and Modern eras. Grouping into four sections is intended for the easy analysis, of the struggle between science and religion, so one can know the different characteristics.

Keywords: Science, Religion, Renaissance

Abstrak: Tulisan ini akan menjelaskan pergulatan antara sains dan agama dengan pendekatan kesejarahan. Hubungan kedua mereka dalam sejarah terjadi pada masa Yunani, Islam, masa Renaisans (pencerahan) dan masa modern. Pengelempokan ke dalam empat kelompok tersebut dilakukan untuk memudahkan analisis pergulatan sains dan agama sehingga dapat diketahui perbedaan karakteristik pada setiap periode perkembangan kedua meereka.

Katakunci: Sains, Agama, Renaisans 


\section{Pendahuluan}

Pembahasan tentang pergulatan sains dan agama pada saat ini tetap menarik karena para pemimpin agama kini ramai-ramai menyerang Profesor Stephen Hawking. Dalam buku terbarunya, The Grand Design, fisikawan dunia asal Inggris yang lumpuh dan hidup di atas kursi roda itu menyimpulkan alam semesta bukanlah diciptakan oleh Tuhan. Serangan balik itu tak kurang dipimpin langsung oleh Uskup Agung Canterbury, Rowan Williams. Kepada The Times Uskup William menyatakan, "Iman terhadap Tuhan bukan soal mencari jawaban tentang bagaimana satu hal berkorelasi dengan hal lain di semesta. Ini adalah iman bahwa ada sesuatu yang Maha Cerdas dan Kuasa di mana segala hal di jagat raya ini bergantung pada keberadaanNya. Ilmu fisika saja tak akan mampu memecahkan misteri kenapa tercipta sesuatu dari ketiadaan." Selain itu kritikan juga datang dari berbagai kalangan agamawan di antaranya Vincent Nichols, pemimpin Gereja Katolik Roma di Inggris dan Wales; Lord Sacks, Rabbi Kepala; dan Ibrahim Mogra, imam dan ketua Majelis Muslim Inggris. ${ }^{1}$

Sains dan agama merupakan dua wilayah pengetahuan manusia yang berbeda dari segi epistemologi. Sains yang berkembang saat ini lebih menekankan kepada pengetahuan rasional dan empiris, sedangkan agama merupakan pengetahuan yang bersifat intuitif. ${ }^{2}$ Bagi John Hedley Brooke hubungan di antara kedua mereka dapat berbentuk konflik yaitu sains dan agama saling bertentangan, atau harmoni yaitu baik sains maupun agama saling melengkapi. ${ }^{3}$ Menurut fisikawan Ian G. Barbour, terdapat empat hubungan dalam persoalan itu yakni: konflik, independen, dialog, dan integrasi dan dalam kasus yang ekstrim bahkan bermusuhan. ${ }^{4}$ Bentuk lain dari hubungan sains dan agama adalah dialog dan konfirmasi. ${ }^{5}$

Pergulatan sains dan agama dalam tulisan ini didasarkan pada pendekatan historis, yang dibagi dalam urutan waktu secara umum yaitu pada masa Yunani, Islam, Renaisans dan modern. Pengelompokan dalam empat bagian untuk memudahkan dalam menganalisis pergulatan yang terjadi antara sains dan agama, sehingga diketahui setiap periode perkembangan sains dan agama memiliki ciri khas yang berbeda. 


\section{Masa Yunani: Mitos dan Kelahiran Falsafat}

Muncul falsafat di Yunani setidak-tidaknya ada tiga faktor yang memengaruhinya: pertama, bangsa Yunani seperti bangsa-bangsa yang ada di wilayah sekitarnya memiliki mitologi. ${ }^{6}$ Mitologi itu dapat dianggap sebagai perintis yang mendahului falsafat, karena mitos-mitos sudah merupakan percobaan untuk mengerti. Kedua, Bangsa Yunani telah memiliki kesusastraan seperti puisi karya Homer (8 SM) dengan judul Iliad dan Odyssey sehingga ikut memengaruhi munculnya falsafat. Ketiga, pengaruh ilmu yang berkembang saat itu di wilayah sekitarnya. Orang Yunani berhutang budi kepada bangsa lain karena telah mendapatkan ilmu, seperti ilmu hitung dari Mesir, ilmu astronomi dari Babylonia.

Mitologi merupakan suatu faktor yang mendahului falsafat dan memersiapkani ke arah timbul falsafat. ${ }^{7}$ Failasuf-failasuf pertama menerima obyek penyelidikannya dari mitologi, yaitu alam semesta dan kejadian-kejadian yang setiap orang dapat saksikan di dalamnya. ${ }^{8}$ Mitologi Yunani sungguhpun menjawab pertanyaan-pertanyaan tentang alam semesta tetapi jawaban-jawaban tersebut tanpa kontrol rasio. Sedangkan para failasuf menjawab pertanyaan-pertanyaan tentang alam dengan pendekatan rasional, sehingga ada perbedaan dan mengakibatkan perdebatan di antara mitologi dan falsafat. ${ }^{9}$

Mitos dapat menunjukkan kepada dongengan-dongengan, biasanya merupakan dongengan dengan binatang-binatang sebagai pelaku; tujuannya adalah untuk memberi moral atau prinsip tindakan dan bukan untuk meriwayatkan suatu kejadian dalam sejarah secara terperinci. Arti yang sesungguhnya sangat bergantung kepada konteks keagamaan; kebanyakan ahli-ahli falsafat agama dan para ahli teologi agama-agama besar tidak mengajarkan bahwa tiap-tiap perkataan dalam kitab suci mereka harus dipahami secara harfiah, tetapi dengan cara berpikir tentang kebenaran-kebenaran yang tertinggi. Bahasa sebagai bentuk pemikiran dan ekspresi tentang kebenaran yang mutlak, dirasakan tidak mampu untuk membentangkan kebenaran yang mutlak. Kata-kata hanya memunyai kemampuan yang sangat terbatas untuk memahami arti kata-kata Tuhan, cinta, maksud.

Sejak abad ke-6 SM. rasio telah menggantikan mitos. Mitologi yang menjadi kepercayaan dan merupakan bentuk keberagamaan 
bangsa Yunani pada saat itu, telah berkembang pada dua arah yaitu pertama, penjelasan alam semesta secara mistis di luar sajak-sajak kepahlawanan. Kedua pada pemikiran tentang etika, seperti yang tertuang dalam cerita Zeus. Pemikiran mitologi tersebut merupakan bagian dari evolusi ide untuk menuju pada pemikiran falsafat.

Seluruh falsafat Yunani dapat dianggap sebagai suatu pergumulan yang panjang antara mitos dan rasio. Para failasuf pertama memandang dunia dengan cara yang belum pernah dipraktikkan orang lain. Mereka mulai berpikir sendiri di belakang kejadiankejadian yang dapat diamati oleh umum. Mereka mencari suatu keterangan yang memungkinkan untuk mengerti kejadian-kejadian itu. Dalam masyarakat Yunani yang tradisional, pelangi adalah seorang dewi yang bertugas sebagai pesuruh bagi dewa-dewa lain. Tetapi Xenophanes (4 SM.), salah seorang di antara failasuf-failasuf pertama, mengatakan bahwa pelangi merupakan suatu awan. Kirakira satu abad sesudahnya, Anaxagoras (3 SM.) sudah mengerti bahwa pelangi disebabkan oleh pantulan sinar matahari dalam awan-awan. Penjelasan rasional tersebut dapat dibuktikan dan dikritik dalam suasana yang rasional.

Sama halnya dengan orang Yunani, orang-orang Mesir kuno dan kebanyakan kebudayaan Mediterania timur menjelaskan asalusul dan hakikat alam semesta dalam kerangka tindakan-tindakan dan emosi-emosi dewa-dewi yang persis manusia. Dimulai dengan Thales (625-547 SM.) dan para failasuf pra-Sokratis lainnya, kisah yang lazim digantikan, penjelasan-penjelasan menjadi makin ilmiah, makin "naturalistis", makin materialistis. Para pemikir awal Yunani ini memuja suatu rasionalitas yang berperasaan dan menekankan pada sebab-sebab material ketimbang puisi spekulatif dan perilaku para dewa-dewi yang berada di balik layar.

Watak Tuhan dalam tradisi Yunani mencakup dua unsur, yaitu unsur agama dan unsur falsafat. Ide pertama tentang Tuhan terdapat dalam Iliad dan Odyssey karya Homer. Dalam epik (syair-syair pahlawan) tersebut, digambarkan ada dewa-dewa yang memerintah alam, yang paling penting adalah Zeus, dewa keteraturan. Ia adalah mahakuasa selama mengikuti tugasnya; tetapi jika menyeleweng akan terjadi kekacauan dalam alam. Zeus memunyai anak-anak yang juga 
menjadi dewa-dewa tetapi tidak kekal; ia bukan pencipta alam dan sangat mengikuti kemauannya sendiri dalam menghadapi manusia; hal ini adalah watak dewa-dewa yang lain juga. Dewa-dewa Yunani, dan kemudian dewa-dewa Romawi, adalah sangat penting dari segi politik; mereka itu mewakili dewa-dewa penjaga tata tertib dan kemakmuran; semua warga negara diharap ikut serta dalam upacara keagamaan umum sebagai tanda kejujuran dan loyalitas mereka. Dewa-dewa semacam itu sangat tidak memuaskan bagi orang-orang Yunani yang berpikir. Terdapat orang-orang Yunani yang berusaha memahami sumber wujud dengan memergunakan akal mereka.

Pada abad ke-5 dan ke-4 SM., suatu sistem falsafat besar dikembangkan oleh failasuf Yunani Plato; sistemnya merupakan puncak dari usaha-usaha orang-orang sebelumnya digabungkan dengan buah pikirannya sendiri. Dalam mencari benda yang tidak berubah dan abadi, Plato kemudian berpikir bahwa hanya benda yang berada di luar alam, di luar ruang dan waktu, yang dapat menjadi realitas tertinggi. Tuhan bagi Plato adalah esensi atau ide dari yang baik. Zat yang transenden (dan alam ini merupakan partisipasi refleksi) zat yang sempurna.

Uraian di atas adalah tentang hubungan keyakinan masyarakat Yunani terhadap para dewa-dewa yang dikenal dengan mitos dan pengetahuan rasional yang dikenal dengan falsafat, maka dapat dikatakan bahwa peran mitos yang ada pada masyarakat Yunani dalam perjalanannya telah digantikan oleh peran falsafat. Falsafat sebagai pengetahuan rasional telah mampu memberikan penjelasanpenjelasan ilmiah, yang selama ini tidak pernah dilakukan oleh masyarakat Yunani.

\section{Masa Islam: Penerimaan dan Pengembangan Ilmu dalam Islam}

Perkembangan ilmu di dunia Islam masa klasik ditandai dengan kemunculan perpustakaan-perpustakaan di wilayah Islam. Perpustakaan 'Abbāsīyah di Baghdad dinamakan dengan "Bayt alHikmah" yang didirikan oleh Khilafah al-Ma'mūn (813-833 M). Peran utama perpustakaan Bayt al-Hikmah adalah menyimpan terjemahan ilmu-ilmu Yunani. ${ }^{10}$ Para pembesar Spanyol yang menjadi penerus Bani Umayyah pada tahun 1031 menjadi terkenal dengan 
perpustakaan-perpustakaan mereka di Saragossa, Granada, Toledo dan di tempat-tempat lain. Di Mesir, para wazir pun memunyai perpustakaan-perpustakaan yang besar. Wazir Khalifah Fāṭimīyah, al-Azīz, pernah mengeluarkan uang sebesar seribu dinar per bulan untuk membayar para ilmuwan, sekretaris dan penjilid buku.

Pengetahuan ilmiah orang Arab pada mulanya sangat terbatas dan secara umum bersandar pada mitologi. Orang-orang yang punya rasa ingin tahu yang keras, begitu masuk Islam, tertarik pada pengetahuan kuno yang secara tiba-tiba mereka ketahui. Segera mereka melihat manfaat dari pengetahuan tersebut bagi mereka, terutama dengan perintah agama baru ini untuk meneliti jagad raya dan menemukan realitas ciptaan Tuhan. Al-Qur'ān tidak melarang penyelidikan jagad raya; sebaliknya justeru menganjurkan kegiatan ini, sebab penggunaan pengetahuan dan akal secara benar hanya akan menghasilkan kebaikan. Itulah sebab ilmuwan-ilmuwan masa awal secara terbuka mengambil pengetahuan baru ini dan menggabungkannya ke dalam kerangka kerja intelektual mereka. Al-Qur'ān telah membangkitkan semangat ingin tahu umat Islam dengan adanya ayat mutasyābihāt. Ayat tersebut membutuhkan pemahaman rasional dan pengetahuan yang mendalam agar dapat penafsiran yang sesuai.

Mengikuti tradisi para multi-disipliner Yunani, ilmuwanilmuwan di dunia Islam juga melakukan kajian di semua bidang pengetahuan. Penafsiran atas pernyataan al-Qur'ān untuk menyelidiki jagad raya terus mendorong penelitian mereka. Setelah menyerap karya-karya terjemahan yang berasal dari dunia Yunani dan Persia, ilmuwan-ilmuwan Muslim melakukan kajian secara bebas. Motivasi kaum Muslim melakukan gerakan intelektual di berbagai negara seperti Mesir, Syria, Irak dan Iran serta negara-negara lainnya tidak lain untuk kesuksesan kekuasaan dan juga untuk rasa ingin.

Ajaran paling mendasar yang memandu pemikiran ilmiah Islam menyatakan bahwa al-Qur'ān mengandung semua kebenaran dan pengetahuan: pertama, prinsip-prinsip semua pengetahuan ada dalam al-Qur'ān; dan kedua, al-Qur'ān dan Hadìts mendefinisikan lingkungan dan nilai-nilai yang inheren dalam pengembangan ilmu. Kedua premis pokok ini mendasari pandangan Islam bahwa semua pengetahuan sesuai dengan Akal Universal dan dengan Tuhan. ${ }^{11}$ 
Falsafat yang merupakan bentuk pengetahuan rasional telah saling memengaruhi dengan pengetahuan agama terutama teologi. ${ }^{12}$ Aliran-aliran teologi dalam Islam seperti Mu'tazilah dan Asy'arīyah dibangun di atas landasan argumentasi falsafat Yunani. Hubungan antara falsafat dan agama direspon oleh kalangan ulama saat itu dengan beragam, ada yang berusaha untuk mencari titik temu di antara keduanya seperti al-Kindī, al-Fārābī dan juga Ibn Sīnā, atau malah memusuhi falsafat seperti aliran Asy'arīyah. ${ }^{13}$

Dalam kontaknya dengan pengetahuan baik yang dari Timur maupun Yunani, umat Islam hanya mengambil informasi yang mereka butuhkan. Mereka tidak mengambil aspek-aspek intelektual dan tradisi kultural Timur dan Yunani yang bertentangan dengan ajaran. Pengetahuan ilmiah yang mereka temui di Mesopotamia dan JundiShapur dianggap netral dan karenanya dengan segera diambil. Dalam matematika, orang Islam menemukan satu kunci untuk memahami simbolisme dunia fisik baik dalam tradisi Timur maupun Yunani, angka-angka mencakup arti kualitatif dan kuantitatif sekaligus.

Sumbangan terpenting pertama para ilmuwan Arab muncul pada pertengahan abad ke-8 hingga ke-9, terutama dalam bidang kimia. Namun berbeda dari para alkimiawan Aleksandria yang tertutup, para alkimiawan Arab lebih terbuka. Mereka menyumbangkan berbagai karya penting yang sangat membantu melicinkan pengembangan ilmu kimia beberapa abad kemudian di Eropa Barat. Awalan al- yang muncul dalam nama senyawa kimia seperti alkohol, alkana, alkali, bahkan alkimia sendiri merupakan bekas yang mengingatkan pada asal usul Arabnya. ${ }^{14}$

Dua abad kemudian, barulah muncul sumbangan penting para ilmuwan Arab dalam bidang fisika dan astronomi. Dalam bidang fisika, khususnya optik, yang patut dicatat adalah sumbangan alHasan ibn al-Haytsām atau al-Hazen (965-1038) dari Kairo, Mesir. Ia memelajari pemantulan cahaya pada cermin berpermukaan bola. Melalui kajiannya terhadap pembiasan cahaya, ia dapati bahwa hukum bias Ptolomeus hanyalah benar untuk sudut-sudut kecil. Astronomi menawarkan satu cara fungsional untuk mengamati gerakan benda-benda angkasa, tidak saja untuk menentukan waktu, tetapi juga untuk memahami kejadian-kejadian alam. 
Hubungan ilmu dan agama pada masa kejayaan Islam merupakan sebuah hubungan yang sangat harmonis di antara keduanya. Bahkan dapat menjadi contoh bagi pengembangan ilmu dan agama sepanjang sejarah peradaban manusia sampai saat ini. ${ }^{15}$ Islam sebagai agama dapat menerima warisan kebudayaan yang telah dikembangkan oleh bangsa Yunani dan kemudian disesuaikan dengan ajaran-ajaran Islam.

\section{Masa Renaisans: Ilmu Melawan Dominasi Gereja}

Kata Renaissance dari bahasa Inggris berarti: kelahiran kembali. Secara historis Renaisan adalah suatu gerakan yang meliputi suatu zaman di mana orang merasa dirinya sebagai telah dilahirkan kembali dalam keadaban. Dalam kelahiran kembali itu orang kembali kepada sumber-sumber yang murni bagi pengetahuan dan keindahan. Awal gerakan pembaharuan di bidang kerohanian, kemasyarakatan dan kegerejaan telah dimulai pada pertengahan abad ke-14 di Italia, jadi masih dalam Abad Pertengahan. Gerakan pembaharuan ini dilakukan oleh para orang humanis Italia. ${ }^{16}$ Tujuan pertama gerakan para humanis Italia ialah merealisasikan kesempurnaan pandangan hidup Kristiani, yang dilaksanakannya dengan mengaitkan hikmah kuno dengan wahyu, dan dengan memberi kepastian kepada gereja, bahwa sifat pikiran-pikiran klasik itu tidak dapat binasa.

Beberapa pokok pemikiran masa Renaisan adalah sebagai berikut: pertama, gerakan humanisme berusaha tidak saja untuk menerjemahkan sumber-sumber Yunani dan Romawi, tetapi juga mencari nilai atau gaya hidup manusia yang terkandung di dalamnya. ${ }^{17}$ Kedua, penolakan tradisi Aristotelian Abad Pertengahan; ketiga, akademi Florentina merupakan suatu konsekuensi penolakan Aristotelian; keempat, pemikiran Renaisan juga terbuka kepada ilmuilmu yang baru mulai terbentuk; dan terakhir, dalam lapisan agama periode ini ditandai oleh ketidakpuasan pada kemapanan, yang mengarah kepada reformasi Protestan.

Unsur-unsur Renaisan yang memengaruhi falsafat ialah: humanisme, kebangkitan untuk memelajari sastera klasik dan penyambutan yang dengan semangat atas realitas hidup ini. Dalam Renaisan dunia diterima seperti apa adanya, sebab orang merasa kerasan (at home) di dunia dan menghargai sekali kepada hal-hal yang 
baik dari hidup ini. ${ }^{18}$ Selain dari itu, karena adanya perspektif baru bagi kesenian dan kesusasteraan maka orang menjadi makin optimis. Hal ini diperkuat lagi dengan adanya penemuan-penemuan di bidang ilmu dan penemuan-penemuan benua baru, yang mengakibatkan timbulnya pikiran-pikiran baru di segala bidang hidup. ${ }^{19}$

Pada zaman Renaisan ada banyak sekali penemuan-penemuan. Penemuan-penemuan itu di antaranya ialah penemuan metode ilmiah oleh Roger Bacon (1214-1292 M.) dengan pendekatan induktif. ${ }^{20} \mathrm{R}$. Bacon melihat bahwa Aristoteles telah mengembangkan cara berpikir dari observasi bagian-bagian yang partikuler kemudian ditarik kesimpulan yang universal. Oleh R. Bacon pendekatan tersebut digunakan dalam pengetahuan yang bersifat empiris, yang digunakan untuk ilmu-ilmu alam. Namun demikian, R. Bacon belum melakukan model penelitian eksperimen yang empiris karena dalam tulisannya tentang ilmu masih bercampur dengan penjelasan astrologi.

Nicolaus Copernicus (1473-1543), seorang tokoh gereja yang ortodoks, menemukan bahwa matahari berada di pusat jagat raya, dan bahwa bumi memunyai dua macam gerak, yaitu: perputaran seharihari pada porosnya dan perputaran tahunan mengitari matahari. ${ }^{21}$ Akan tetapi karena takut bahwa ia dikucilkan dari Gereja karena pendapatnya itu, maka ia menangguhkan penerbitannya. Baru pada tahun 1543, yaitu tahun kematiannya, penemuannya itu diterbitkan oleh temannya. Buku itu dipersembahkan kepada Sri Paus. Sampai pada zaman Galileo buku ini tidak dicurigai dan dibiarkan beredar. Orang masih menganggapnya hanya sebagai salah satu pendapat di samping pendapat Ptolomeus yang merajai pandangan pada waktu itu. Suasana pandangan Copernicus memang belum modern.

Galileo Galilei (1564-1642) adalah penemu yang terbesar di bidang ilmu, dengan Newton sebagai satu-satunya pengecualian. Ialah yang mula-mula menemukan pentingnya akselerasi dalam dinamika. Yang dimaksud dengan akselerasi adalah perubahan kecepatan, baik dalam besarnya maupun dalam arah geraknya. ${ }^{22}$ Ia juga yang mula-mula menetapkan hukum benda yang jatuh. Jika sesuatu jatuh dengan bebas, artinya: dalam ruang kosong, kecepatan kejatuhan itu tetap, akan tetapi dalam ruang yang tidak kosong ada gerak hawa yang berlawanan dengan gerak kejatuhan itu, sehingga kecepatannya 
berubah. Perubahan kecepatan (akselerasi) itu tetap sama bagi segala macam benda, baik yang berat maupun yang ringan, baik yang besar maupun yang kecil. Ia menerima pandangan yang mengajarkan, bahwa matahari menjadi pusat jagat raya, seperti yang ditemukan oleh Copernicus. Penemuan Galilei ini menggoncangkan Gereja, yang menuntut supaya Galilei menarik kembali ajaran-ajarannya itu. Hal ini terjadi pada tahun 1616 secara tersembunyi, dan pada tahun 1632 secara terbuka. ${ }^{23}$

Orang yang merintis suatu perkembangan besar pada abad ke-17 adalah Francis Bacon (1561-1626), yang bermaksud meninggalkan ilmu yang lama dan mengusahakan yang baru. Hal ini disebabkan karena ilmu yang lama dipandang sebagai tidak memberi kemajuan, tidak memberi hasil yang bermanfaat dan tidak menghasilkan halhal baru yang berfaedah bagi hidup. Francis Bacon dapat dipandang sebagai orang yang meletakkan dasar-dasar bagi metode induksi yang modern, dan menjadi pelopor dalam usaha untuk menyistimatisir secara logis prosedur ilmiah. Seluruh asas falsafatnya bersifat praktis, yaitu untuk menjadikan manusia menguasai kekuatan-kekuatan alam dengan perantaraan penemuan-penemuan ilmiah.

Dari pemaparan di atas tentang hubungan ilmu dan agama pada masa Renaisan dapat disimpulkan bahwa antara ilmu dan agama terjadi konflik. Pada masa sebelum muncul gerakan Renaisan, agama Kristiani menjadi agama yang sangat dominan dalam memerintah dan mengatur perkembangan masyarakat. Pendapat ilmuwan harus sesuai dengan ajaran Gereja meskipun ajaran Gereja tidak sesuai dengan perkembangan pengetahuan pada masa itu. Ketidakpuasan terhadap kekuasaan Gereja diperlihatkan oleh para seniman, ilmuwan dan lainya dengan membuat gerakan yang dinamakan gerakan Renaisan. Gerakan tersebut mampu mengurangi dominasi gereja terhadap perkembangan pengetahuan dan seni.

\section{Masa Modern: Saintisme dan Penolakan Ilmu Sekuler terhadap Agama}

Masa modern yang dimulai sekitar abad ke-19 dan 20 Masehi ditandai dengan perkembangan sains sekuler yang sangat pesat baik sains alam, sejarah, ekonomi dan lainnya. ${ }^{24}$ Pada masa ini 
juga berkembang paham saintisme. Secara umum, saintisme bisa dideskripsikan sebagai berikut: sesuai dengan dogma rasionalis, yang memandang inteligensi manusia sebagai ukuran seluruh inteligibilitas, saintisme membatasi rasionalisme tersebut dalam batasbatas sains saja, sehingga roh manusia sendiri direduksikan sampai dimensi ilmiah saja. Hanya ilmu-ilmu positif_ilmu kimia, ilmu fisika, ilmu astronomi-yang mampu memecahkan segala masalah dan memberikan jawaban yang memuaskan kepada segala tuntutan manusia akan inteligibilitas. Itulah suatu pendapat yang menyamakan seluruh realitas dengan hal yang dapat dimengerti secara ilmiah. ${ }^{25}$

Perkembangan pandangan baru atas hidup bermula dari ilmu alam, yakni fisika. Copernicus (1473-1543) dan Galilei (15641642) yang mengemukakan suatu pandangan baru tentang bumi ini; mereka membuktikan bahwa bumi ini tidak dapat dipandang lagi sebagai pusat semesta alam yang diciptakan Tuhan. Di samping itu mereka merintis jalan untuk menanggapi semesta alam melalui ilmu fisika. Sejak Newton (1642-1727) seluruh alam ini dipandang sebagai sejumlah atom, yang menurut hukum-hukum alam tertentu, tanpa adanya pengaruh langsung dari Tuhan. ${ }^{26}$ Pada abad yang ke-19 biologi ikut mengubah pandangan dunia. Darwin (1809-1882) dan penganut-penganutnya membuktikan bahwa manusia tidak berasal dari Tuhan secara langsung; bertambah keyakinan bahwa manusia merupakan pelengkap suatu evolusi alam, yang berdasarkan prinsip "pilihan alam" (natural selection).

Perkembangan ilmu sejarah membuktikan bahwa kitab suci tidak berasal dari Tuhan secara langsung, melainkan berkembang sesuai dengan perkembangan masyarakat ketika itu. Kemudian pada abad ini psikologi Freud (1856-1939) menjelaskan bahwa dalam segala tingkah laku hidup bawah sadar manusia sangat besar pengaruhnya. Maka bukan Tuhan yang menentukan arah hidup, sekalipun tidak secara langsung, melainkan nafsu-nafsu yang membentuk bawah sadar psike manusia.

Hubungan ilmu dan agama pada masa modern semakin renggang. Ilmu modern yang dibangun di atas fondasi empiris dan rasional semakin jauh meninggalkan agama yang bersifat intuitif. Kondisi yang demikian, telah memengaruhi pandangan-pandangan 
keagamaan terutama Kristen yang menjadi agama mayoritas di Barat. Pengaruh terbesar dari perkembangan ilmu yang ada dalam teologi Kristen adalah gagasan tentang "Tuhan Mati”.

\section{Simpulan}

Sains yang berkembang pada saat ini baik sains teoritis maupun aplikatif telah memberikan sesuatu yang sangat berharga bagi kehidupan manusia. Peran sains tidak dapat diabaikan begitu saja karena sejak awal perkembangaanya telah mengubah cara pandang manusia tentang dirinya dan alam sekitarnya sesuai dengan pandangan sains. Begitu juga peran agama, yang tidak dibatasi hanya pada pengetahuan empiris dan rasional saja seperti yang terjadi dalam sains. Agama memberikan penjelasan tentang misteri-misteri kehidupan secara intuitif. Mengabaikan sains ataupun agama mengakibatkan hilangnya keseimbangan dan keharmonisan baik pada manusia maupun alam. Pergulatan sains dan agama yang berdampak negatif selayaknya harus dihindarkan, karena baik sains maupun agama dapat menjelaskan dan menjawab permasalahan-permasalahan kehidupan sesuai dengan wilayah kajian masing-masing.

\section{Catatan Akhir:}

1 www.vivanews.com diakses 28 September 2010.

2 Syed Muhammad Naquib al-Attas, Prolegomena: To the Metaphysics of Islam (Kuala Lumpur, 2001), 177.

3 John Hedley Brooke, Science and Religion: Some Historical Perspectives (Cambridge: Cambridge University Press, 1998), 33.

4 Ian G. Barbour, When Science Meets Religion (New York: Harper San Francisco, 2000), 3.

5 John F. Haught, Perjumpaan Sains dan Agama: Dari Konflik ke Dialog, terj. Fransiskus Borgias (Bandung: Mizan, 2004), 2.

6 K. Bertens, Sejarah Falsafat Yunani (Yogyakarta: Kanisius, 1999), 19.

7 W. Wildelband, History of Ancient Philosophy (New York: Dover Publication, 1956), 26.

8 F. Copleston, A History of Philosophy (USA: The Newmann Press, 1985), 13.

9 Forrest E.Baird (ed.), Medieval Philosophy, Philosophic Classics (New Jersey: Prentice Hall, 1997), Vol. II, 23.

${ }^{10}$ J. Pedersen, Fajar Intelektualisme Islam: Buku dan Sejarah Penyebaran Informasi di Dunia Arab, terj. Alwiyah Abdurrahman (Bandung: Mizan, 1996), 14. 
${ }^{11}$ Charles Michael Stanton, Pendidikan Tinggi Dalam Islam: Sejarah dan Peranannya Dalam Kemajuan Ilmu, terj. H. Afandi dan Hasan Asari (Jakarta: Logos, 1994), 121.

${ }^{12}$ Dalam aliran teologi Islam di antara Mu'tazilah telah menjadikan rasio sebagai sumber pengetahuan selain wahyu. Lih. Harun Nasution, Teologi Islam: Aliranaliran Sejarah Analisa Perbandingan (Jakarta: UI Press, 2002), 40.

${ }^{13}$ Majid Fakhry, A History of Islamic Philosophy (New York: Columbia University Press, 1983), 185.

${ }^{14}$ Hans J. Wospakrik, Dari Atomos Hingga Quark (Jakarta: Universitas Atma Jaya, 2005), 24.

${ }^{15}$ M.M Sharif (ed.), A History of Muslim Philosophy (Otto Harassowitz Wiesbaden, 1963), vol 1, 68.

${ }^{16}$ Peter A. French, et.al. Midwest Studies in Philosophy Volume V 1980 Studies in Epistemology (Minneapolis: University of Minnesota Press, 1980), 348.

${ }^{17}$ Lihat juga Cesare Vasoli, "The Renaisance Concept of Philosophy", dalam Charles B. Schmitt dan Quentin Skinner (ed.), The Cambrige History of Renaissance Philosophy (Cambrige University Press: 2000), 70.

${ }^{18}$ Colin Brown, Philosophy and the Christian Faith (USA: Intervarsity Press, Downer Grove, 2007), 67.

${ }^{19}$ Lacey A.R., A. Dictionary of Philosophy (New York: Routledge, 2000), 78.

${ }^{20}$ Forrest E. Baird (ed.), Medieval Philosophy, Philosophic Classics (New Jersey: Prentice Hall, 1997), Vol. II, 273.

${ }^{21}$ Robert Maynard Hutchin (ed.), Great Books of the Western World (Chicago: William Benton, 1952), 498.

22 Jacques Dupuis (ed.), The Christian Faith (New York: Alba House, 1995), 72.

${ }^{23}$ Forrest E. Baird (ed.), Medieval Philosophy, Philosophic Classics (New Jersey: Prentice Hall, 1997), Vol. II, 274.

${ }^{24}$ Syed Muhammad Naquib Al-Attas, Islam and Secularism (Kuala lumpur: Muslim Youth Movement of Malaysia, 1978), 102.

${ }^{25}$ Louis Leahy SJ., Aliran-Aliran Besar Ateisme Tinjauan Kritis (Yogyakarta: Kanisius, 1985), 138.

${ }^{26}$ Theo Huijbers, Mencari Allah: Pengantar ke dalam Filsafat Ketuhanan (Yogyakarta: Kanisius, 1992), 243.

\section{Daftar Pustaka}

Al-Attas, Syed Muhammad Naquib. Prolegomena: To the Metaphysics of Islam. Kuala Lumpur: 2001

Baird, Forrest E. Medieval Philosophy, Philosophic Classics. Vol. II, New Jersey: Prentice Hall. 1997

Barbour, Ian G. When Science Meets Religion. New York: Harper San Francisco. 2000 
Brooke, John Hedley. Science and Religion: Some Historical Perspectives. Cambridge: Cambridge University Press. 1998

Bertens, K. Sejarah Falsafat Yunani. Yogyakarta: Kanisius. 1999

Brown, Colin. Philosophy and the Christian Faith. USA: Intervarsity Press. Downer Grove. 2007

Copleston, Frederick. A History of Philosophy. USA: The Newmann Press. 1985

Fakhry, Majid. A History of Islamic Philosophy. New York: Columbia University Press. 1983

French, Peter A. et.al. Midwest Studies in Philosophy Volume V 1980 Studies in Epistemology. Minneapolis: University of Minnesota Press. 1980

Haught, John F. Perjumpaan Sains dan Agama: Dari Konflik ke Dialog, terj. Fransiskus Borgias. Bandung: Mizan. 2004

Huijbers, Theo. Mencari Allah: Pengantar ke dalam Filsafat Ketuhanan. Yogyakarta: Kanisius. 1992

Hutchin, Robert Maynard (ed.). Great Books of the Western World. Chicago: William Benton. 1952

Nasution, Harun. Teologi Islam: Aliran-aliran Sejarah Analisa Perbandingan. Jakarta: UI Press. 2002

R, Lacey A. A. Dictionary of Philosophy. New York: Routledge. 2000

Sharif, M.M. A History of Muslim Philosophy. vol 1, Otto Harassowitz Wiesbaden: 1963

SJ, Louis Leahy. Aliran-Aliran Besar Ateisme Tinjauan Kritis. Yogyakarta: Kanisius. 1985

Stanton, Charles Michael. Pendidikan Tinggi Dalam Islam: Sejarah dan Peranannya Dalam Kemajuan Ilmu, terj. H. Afandi dan Hasan Asari. Jakarta: Logos. 1994

Vasoli, Cesare. The Renaisance Concept of Philosophy. dalam Charles B. Schmitt dan Quentin Skinner (ed.). The Cambrige History of Renaissance Philosophy. Cambrige University Press: 2000

Wildelband, W. History of Ancient Philosophy. New York: Dover Publication. 1956

Wospakrik, Hans J. Dari Atomos Hingga Quark. Jakarta: Universitas Atma Jaya. 2005. 